The Social Sciences in Modern Japan 


\section{TWENTIETH-CENTURY JAPAN:}

\section{THE EMERGENCE OF A WORLD POWER}

Irwin Scheiner, Editor

I. Labor and Imperial Democracy in Prewar Japan, by Andrew Gordon

2. Complicit Fictions: The Subject in the Modern Japanese Prose Narrative, by James A. Fujii

3. The Making of a Japanese Periphery, I750-1920, by Kären Wigen

4. The Abacus and the Sword: The Japanese Penetration of Korea, I895I9Io, by Peter Duus

5. Authenticating Culture in Imperial Japan, by Leslie Pincus

6. Splendid Monarchy: Power and Pageantry in Modern Japan, by T. Fujitani

7. Marketing the Menacing Fetus in Japan, by Helen Hardacre

8. Japan's Total Empire: Manchuria and the Culture of Wartime Imperialism, by Louise Young

9. Mirror of Modernity: Invented Traditions of Modern Japan, edited by Stephen Vlastos

Io. Hiroshima Traces: Time, Space, and the Dialectics of Memory, by Lisa Yoneyama

I I. MAVO: Japanese Artists and the Avant-Garde, I905-I93I, by Gennifer Weisenfeld

I2. Reconfiguring Modernity: Concepts of Nature in Japanese Political Ideology, by Julia Adeney Thomas

I3. The City as Subject: Seki Hajime and the Reinvention of Modern Osaka, by Jeffrey E. Hanes

14. Perfectly Japanese: Making Families in an Era of Upheaval, by Merry Isaacs White

I 5. The Social Sciences in Modern Japan: The Marxian and Modernist Traditions, by Andrew E. Barshay 


\section{The Social Sciences in Modern Japan}

The Marxian and Modernist Traditions

\section{Andrew E. Barshay}


University of California Press

Berkeley and Los Angeles, California

University of California Press, Ltd.

London, England

First paperback printing 2007

(C) 2004 by the Regents of the University of California

Library of Congress Cataloging-in-Publication Data

Barshay, Andrew E.

The social sciences in modern Japan: the marxian and modernist traditions / Andrew E. Barshay.

p. $\mathrm{cm}$.

Includes bibliographical references and index.

ISBN 978-0-520-2538I-o (pbk : alk.)

I. Social sciences-Japan-History.

2. Intellectuals - Japan-History. 3. Socialism-

Japan-History. 4. Democracy-Japan-History. 5. Political culture-Japan - History. I. Title.

H53.J3 В37 2004

300 '.952'0904-dc2I

2003014237

Manufactured in the United States of America

$\begin{array}{llllllllll}\text { I6 } & \text { I5 } & \text { I4 } & \text { I3 } & \text { I2 } & \text { II } & \text { IO } & 09 & 08 & 07\end{array}$

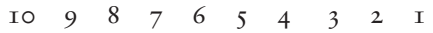

The paper used in this publication is both acid-free and totally chlorine-free (TCF). It meets the minimum

requirements of ANSI/NISO Z39.48-I992 (R I997)

(Permanence of Paper). @) 
For $K$ and I 
